\title{
Specificity Effects and Object Movement In Turkish and Uyghur
}

\author{
Robin Jenkins*
}

\begin{abstract}
This paper examines an object marking pattern in Uyghur where marked objects lose their obligatory specific interpretation under fronting to sentence initial position. This contrasts with the more typical differential object marking pattern found in, e.g., Turkish where marked objects always have a specific interpretation regardless of their position. The Uyghur data, I argue, suggest that a specific interpretation of object DPs does not always correlate with structural height relative to the VP (Diesing 1992). Instead, I propose a new model where a specific interpretation of an object is forced if it passes through a particular position in the structure.
\end{abstract}

Keywords. Turkish; Uyghur; differential object marking; case; scrambling

1. Introduction. This paper presents a typologically novel pattern in Uyghur which concerns the interpretations available to Uyghur direct objects when dislocated from their canonical, Vadjacent position. Like many languages, Uyghur participates in a differential object marking system (DOM) (Comrie 1989; Croft 2002; Aissen 2003; Sinnemäki 2014). Specific objects are marked with dedicated morphology and are structurally higher than unmarked, non-specific objects. This type of specificity-based differential object marking is standardly analyzed in terms of DPs bearing a [+SPECIFIC] feature having licensing requirements which forces movement from their base-generated VP-internal position (Diesing 1992; Bhatt \& Anagnostopoulou 1996; Torrego 1998; Rodríguez-Mondoñedo 2007). Hence, the relative structural height of a DP, i.e. being VP-external, is predicted to strictly correlate with the object DP's specific interpretation.

I show that Uyghur's DOM pattern presents an exception to this correlation between DP structural height and specific interpretation. In Uyghur, when an object is dislocated from its base position and moved to a higher, middle-field, position that object is marked accusative and can only be interpreted as specific. However, further movement to a sentence initial position allows for the object to be interpreted as either specific or non-specific. This variability contrasts sharply with other specificity-based DOM languages, e.g. Turkish, where all objects dislocated from their base-position receive a uniform specific interpretation.

In light of the Uyghur facts, I propose an analysis where specificity is not the result of relative height with regard to VP but if the object DP occupies a particular position in the structure. On this analysis, the variability of interpretations available to fronted, sentence initial, DOM objects in Turkish and Uyghur are explained in terms of phasal boundaries. Specifically, whether Spec $v \mathrm{P}$ delimits a phasal edge or not in the language.

1.1. Previous Analyses of SPeCificity-BAsed DOM. Cross-linguistically many languages participate in differential object marking systems where a subset of objects that bear a [+SPECIFIC] feature surface with dedicated morphology. In Spanish (1), [+SPECIFIC, HUMAN] objects must surface with the dative preposition $a$ (Torrego 1998; Rodríguez-Mondoñedo 2007); in Turkish (2), [+SPECIFIC] objects surface with ACC-case morphology (Enç 1991).

\footnotetext{
* Thanks to Željko Bošković, Magdalena Kaufmann, and Adrian Stegovec, and the audience at TU+6 for helpful comments and feedback. Thanks to Shaida Shaoket and Subhi Tarim for sharing their judgments and linguistic insights for Uyghur; thanks to Aliyar Özercan for sharing his insights and judgments on the Turkish data. Author: Robin Jenkins, University of Connecticut (robin.jenkins@uconn.edu)
} 
(1) a. María quiere un abogado

Mary wants a lawyer

'Mary wants a lawyer.'

b. María quiere a un abogado

Mary wants to a lawyer

'Mary wants a certain lawyer.' (Rodríguez-Mondoñedo (2007); (2))

(2) a. Ali kitap oku-du

Ali book read-PST.3SG

'Ali read a book.'

b. Ali kitab-ı oku-du

Ali book-ACC read-PST.3SG

'Ali read a certain book.' 1

Although differing in specific implementations, many accounts of DOM posit that marked object DPs move outside their base-generated VP-internal position to the specifier of a higher functional head (3-b), while unmarked objects remain VP-internal (3-a). (Torrego 1998; RodríguezMondoñedo 2007). ${ }^{2}$

(3) a. $\left[\ldots\left[\mathrm{vP} V \mathrm{DP}_{- \text {SPECIFIC }}\right]\right]$

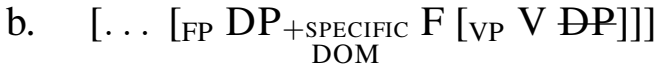

On such an analysis, where [+SPECIFIC] DPs must evacuate the VP, the following generalization (4) is predicted for languages with specificity-based DOM systems (cf. Diesing (1992)).

(4) If DP is [+SPECIFIC], then DP c-commands (i.e. is not dominated by) VP

(4) as a descriptive generalization, states that specific objects must be higher in the structure than VP, i.e. they are VP-external. This generalization is assumed to hold on any account where marked objects are licensed by and move to the Spec of a higher functional head (cf.(3-b)).

2. Overview of Uyghur Differential Object Marking. Turkish and Uyghur both participate in a differential object marking system where specific objects are marked with accusative case morphology, while non-specific objects are unmarked. (5), (6) illustrate the Turkish pattern with the accusative marker $(-(y) I)$.

(5) a. Ali kitap oku-du

Ali book read-PST.3SG

'Ali read a book.'

b. Ali kitab-ı oku-du

Ali book-ACC read-PST.3SG

'Ali read a certain book.'

(6) a. (ben) doktor ar1-yor-um

$1 \mathrm{SG}$ doctor look.for-PROG-1SG

'I am looking for a doctor.'

${ }^{1}$ Glosses throughout follow Leipzig glossing conventions unless example is taken from other work. In which case, the gloss is consistent with the source.

${ }^{2}$ DOM case morphology on these accounts can either be taken as a reflex of AGREE (Chomsky 2001) or the result of the object DP entering into case competition with a higher DP (Marantz 1991; Baker \& Vinokurova 2010). 
b. (ben) doktor-u ar1-yor-um

1SG doctor-ACC look.for-PROG-1SG

'I am looking for a certain doctor.' (Kelepir (2001); (119))

Uyghur shows the same pattern as in (7), (8), where non-specific objects are unmarked and specific objects surface with accusative case morphology $(-n i)$.

a. Mehmet mashin xala-y-du

Mehmet car want-NPST-3SG

'Mehmet wants a car.'

b. Mehmet mashina-ni xala-y-du

Mehmet car-ACC want-NPST-3SG

'Mehmet wants a certain car.'

(8) a. (men) doktor izde-wati-men

$1 \mathrm{SG}$ doctor look.for-PROG-1SG

'I am looking for a doctor.'

b. (men) doktor-ni izde-wati-men

$1 \mathrm{SG}$ doctor-ACC look.for-PROG-1SG

'I am looking for a certain doctor.'

2.1. Structural Height of Marked DPs. In both Turkish and Uyghur, ACC-objects are structurally higher than bare, unmarked objects. Two pieces of evidence that suggest that marked objects are structurally higher are (i) adverb placement, and (ii) scope under negation.

In Turkish, ACC-marked objects must precede non-derived, event-modifying manner adverbse.g. hizlı ('quickly'). Conversely, unmarked objects must follow such adverbs (Ö̈türk 2005).

(9) a. Ali (hızlı) kitap (*hızlı) oku-du.

Ali (quickly) book (quickly) read-PST.3SG

'Ali read a book quickly.'

b. Ali (*hılı) kitab-1 (hıll) oku-du.

Ali (quickly) book-ACC (quickly) read-PST.3SG

'Ali read a certain book quickly.' (Öztürk $(2005)$; $(84,85)$ )

The same surface order is observed in Uyghur, where ACC-objects must precede and unmarked objects must follow manner adverbs (tëz, 'quickly').
a. Mehmet (tëz) kitap (*tëz) oqu-di.
Mehmet (quickly) book (quickly) read-PST.3SG
'Mehmet read a book quickly.'
b. Mehmet (*tëz) kitap-ni (tëz) oqu-di.
Mehmet (quickly) book-ACC (quickly) read-PST.3SG
'Mehmet read a certain book quickly.'

Assuming that event-modifying, manner adverbs are VP-adjoined, the distribution of the ACCmarked and bare objects for both Turkish and Uyghur indicates that the marked object DPs move from their base-generated position. That is, marked objects are VP-external. Meanwhile, unmarked objects remain in the base-generated, VP-internal position. ${ }^{3}$

\footnotetext{
${ }^{3}$ An anonymous reviewer noted that in Turkish there is a class of manner adverbs that can precede ACC-objects. E.g.
} 
Further evidence indicates that in both Turkish and Uyghur, marked objects are higher in the structure than unmarked ones. In Turkish, unmarked objects must take narrow scope relative to negation (11-a), while ACC-marked objects can take-wide scope (11-b).

a. Ali kitap oku-ma-di.

Ali book read-NEG-PST.3SG

'Ali didn't read a book' (NEG $>$ book, *book>NEG)

b. Ali kitab-1 oku-ma-dı

Ali book-ACC read-NEG-PST.3SG

'Ali didn't read a certain book' (book>NEG, ?NEG>book) (Kelepir (2001) (cf. (131,132))

The same scope facts obtain in Uyghur. Bare objects must take narrow-scope relative to negation (12-a); ACC-objects can scope outside of negation (12-b).
a. Mehmet kitap oqu-ma-di
Mehmet book read-NEG-PST.3SG
'Mehmet didn't read a book' (NEG>book, *book>NEG)
b. Mehmet kitap-ni oqu-ma-di
Mehmet book-ACC read-NEG-PST.3SG
'Mehmet didn't read a certain book.' (book $>$ NEG, ? NEG $>$ book)

Assuming that scopal relations reflect c-command relation between the object DP and Neg where the DP must c-command Neg to take wide scope, and that Neg is merged above VP, then the scope facts for both Uyghur and Turkish further indicate that ACC-objects are higher in the structure than their unmarked counterparts.

2.2. Scrambling In Turkish And Uyghur. Both Turkish and Uyghur allow for a relatively free ordering of nominals in the clause (see Erguvanl1 (1984); Şener (2010) for Turkish; Hahn (1991); Tömür (2003) for Uyghur). For Turkish, the direct object can be dislocated from its canonical surface V-adjacent position, scrambling over the subject (13). In this configuration, the object must be (i) ACC-marked and (ii) can only receive a specific interpretation.

doktor $_{i} *(\mathbf{u})$ ben $t_{i}$ ar1-yor-um

doctor-ACC $1 \mathrm{SG}$ look.for-PROG-1SG

'I am looking for a certain doctor'

Under the standard analysis where [+SPECIFIC] DPs require licensing from a higher functional head and have to be higher than VP, the interpretation of the object in (13) is expected. Assuming that the object DP has to first move to a licensing position, further movement should preserve the interpretation of the DP given that the DP is still higher than VP after movement.

The same pattern can be observed in Spanish, another differential object marking language (cf. (1)). In (14-a), the object DP marked with dative $a$ can only receive a specific interpretation. When topicalized (14-b), $a$-marking is required and the DP can only be interpreted as specific in

the manner adverb yavaş ('slowly') has a derived form yavaş-ça which can precede ACC-objects as in (i). Following previous work (Üntak-Tarhan 2006; Kamali 2011), I assume that these adverbs' adjunction site is higher than VP.

(i) Ali (yavaşça) kitab-1 (yavaşça) oku-du

Ali slowly book-ACC slowly read-PST.3SG

'Ali read a certain book slowly.' (Üntak-Tarhan (2006), (25)) 
this configuration. ${ }^{4}$

(14) a. Habian incluido (a) dos catedráticos en la lista

They.had included (to) two professors in the list

'They had included (the) two professors in the list'

b. *(A) dos catedráticos ${ }_{i}$, los habian incluido $t_{i}$ en la lista

(to) two professors, them they.had included in the list

'The two professors, they included in the list.' (G. Martínez-Vera, p.c.)

This pattern too is expected given that $a$ marked objects are assumed to be VP external. As with Turkish, movement to a higher position as in (14-b), preserves interpretation.

Uyghur's object scrambling facts stand in sharp contrast to the Turkish pattern. As in Turkish, Uyghur's scrambled objects must surface with ACC-case morphology. But in Uyghur, scrambled objects are not obligatorily specific. Rather, objects can be interpreted as either specific or non-specific when scrambled over the subject (15).

Doktor $_{i^{-}} *(\mathbf{n i})$ men $t_{i}$ izde-wati-men

doctor-ACC 1SG look.for-PROG-1SG

'I am looking for a certain doctor/ some doctor or another'

Further, it is only this clause-initial position in Uyghur which allows for a non-specific interpretation of the ACC-object. When the ACC-object is in a clause-medial position as in (16-a), (16-b), it can only be interpreted as specific (as with Turkish as illustrated in (17-a),(17-b)). ${ }^{5}$
a. Mehmet xet-ni Aliyë-gë yaz-i-du
Mehmet letter-ACC Aliye-DAT write-NPST-3SG
'Mehmet will write a certain letter to Aliyë.'
b. Mehmet xet-ni ete yaz-i-du
Mehmet letter-ACC tomorrow read-NPST-3SG
'Mehmet will write a certain letter tomorrow.'
a. Ali kitab-1 Hasan-a ver-di
Ali book-ACC Hasan-DAT give-PST.3SG
'Ali gave the book to Hasan.' (Kornfilt (2003), (30a))
b. Ali kitap-1 dün oku-du
Ali book-ACC yesterday book-PST.3SG
'Ali read the book yesterday.'

The availability of both a specific and non-specific interpretation in (15) is unexpected. First, Uyghur's scrambling facts are an exception to the generalization that VP-external DPs are obligatorily specific (4). Second, under any account of DOM where DOM morphology correlates with a DP bearing a license-requiring feature, which in turn correlates with movement outside of the VP, the Uyghur facts in (15) pose a problem. If only DPs with a feature that requires licensing by

\footnotetext{
${ }^{4}$ It has been observed that in Spanish dative $a$-marking on a direct object is not strictly correlated with DPs bearing specificity feature and can surface on non-specific objects in some cases-e.g. arguments of small clause complements and objects of restructuring verbs (López 2012). The relevant point here, however, is that in Spanish, as in (14-b), the $a$-marked object retains its specificity feature under movement.

${ }^{5}$ Note there is some variability among speakers regarding the interpretation of the direct object in (16-a), (16-b). For some the direct object can have both a specific and non-specific interpretation. At present, there is no clear explanation for this variability and more data is required.
} 
a higher head can evacuate the VP, then only those DPs should be available for movement to a higher position. While this may be the case for Turkish, this is not so in Uyghur.

3. Analysis. As illustrated in the previous section, the Uyghur scrambling facts show that VPexternality is not a sufficient condition for a DP to be interpreted as specific. In other words, the generalization in (4) does not hold for Uyghur's scrambled objects. In light of this, I suggest that the following is the correct generalization over DP height and specific interpretation:

If DP moves to Spec $v \mathrm{P}$, then DP must be [+SPECIFIC]

The key point with regards to (18) is that unlike the previous generalization (4), the interpretation of an object DP does not strictly correlate with its height relative to the VP. In other words, a DP being VP external is not sufficient to guarantee that it will receive a specific interpretation. Instead what forces an object to be interpreted as specific is if the DP occupies a particular structural position: Spec $v \mathrm{P}$.

Note as well that the present analysis is neutral on what mechanism underlies the generalization in (18). One possibility is that $v$ has a semantically-based restriction such that only [+SPECIFIC] DPs can merge into its Spec. Previous analyses have posited that such restrictions are cross-linguistically available for functional heads including $v$ (Harley 2002; Adger \& Harbour 2007; Wiltschko \& Ritter 2015). Another possibility is that if a DP has moved to Spec $v$ P, then it must be interpreted as [+SPECIFIC]. In other words, it is being located in Spec $v \mathbf{P}$ which forces a specific interpretation (rather than only DPs with a specificity feature can move to Spec $v \mathrm{P}$ ).

Following previous work, the present analysis assumes that nominal phrases in both Turkish and Uyghur can be merged into their base position as either DPs or NPs. If the nominal has merged as the latter as in (19), then it pseudo-incorporates with V and remains VP-internal (Mas-

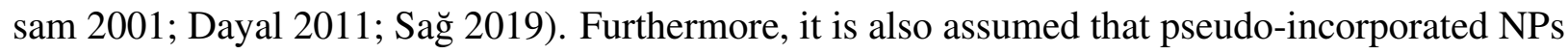
do not require licensing from higher functional heads, do not surface with case morphology, and cannot be interpreted as [+SPECIFIC]. If the object nominal merges as a full DP as in (20), then the object must be licensed by a higher functional head, and crucially, in principle, either have or lack a [+/-SPECIFIC] feature.

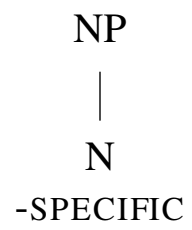

(20)

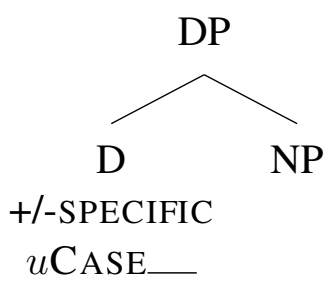

On the present analysis, Turkish (6-b) and Uyghur (7-b) ACC-marked object DPs are first merged in their base position, then move to Spec $v \mathrm{P}$ for licensing as in (21).

(6-b) (ben) doktor-u ar1-yor-um

1 SG doctor-ACC look-for-PROG-1 SG

'I am looking for a certain doctor.'

(7-b) Mehmet mashina-ni xala-y-du

Mehmet car-ACC want-NPST-3SG

'Mehmet wants a certain car' 
(21)

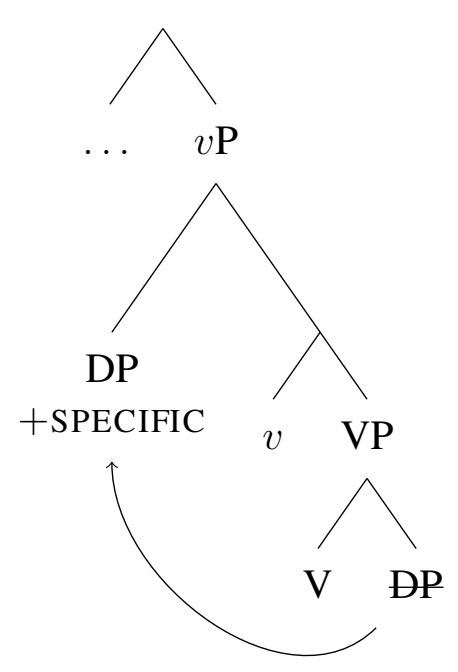

Crucially, although in principle Turkish and Uyghur DPs can be [+/-SPECIFIC] because the the DP must move to Spec $v$ P, only a [+SPECIFIC] interpretation is possible in this position due to (18). Hence, ACC-marked DPs in this position for both Turkish and Uyghur must be interpreted as specific.

3.1. SCRAmbled OBjects. Recall in the previous section that the key contrast between Turkish and Uyghur's scrambled objects was that in the former but not the latter, scrambled objects can only be interpreted as specific in this position ((13), (15) repeated below).

(13) Doktor $_{i} *(\mathbf{u})$ ben $t_{i}$ ar1-yor-um doctor-ACC 1SG look-for.PROG-1SG

'I am looking for a certain doctor.'

(15) Doktor $_{i}{ }^{*}(\mathbf{n i})$ men $t_{i}$ izde-wati-men doctor-ACC 1SG look.for-PROG-1SG

'I am look for a certain doctor/ some doctor or another.'

I propose that the contrasting interpretations observed between Turkish and Uyghur's scrambled objects is due to a difference in phasal boundaries. In Turkish but not in Uyghur $v$ is phase head. Subsequently, in Turkish but not Uyghur scrambling DPs must have Spec $v \mathrm{P}$ as an intermediate landing site due to the Phase Impenetrability Condition, which requires that movement out of a phase proceed through its edge-i.e. its Spec. Per generalization (18), only [+SPECIFIC] DPs can move to Spec $v \mathrm{P}$ as either a final or intermediate landing site. Therefore, in Turkish only [+SPECIFIC] DPs will be able to scramble to higher, left-periphery position, since only those DPs can move to the phase edge- Spec $v \mathrm{P}$. The Turkish-type scrambling derivation is illustrated below in (22). 


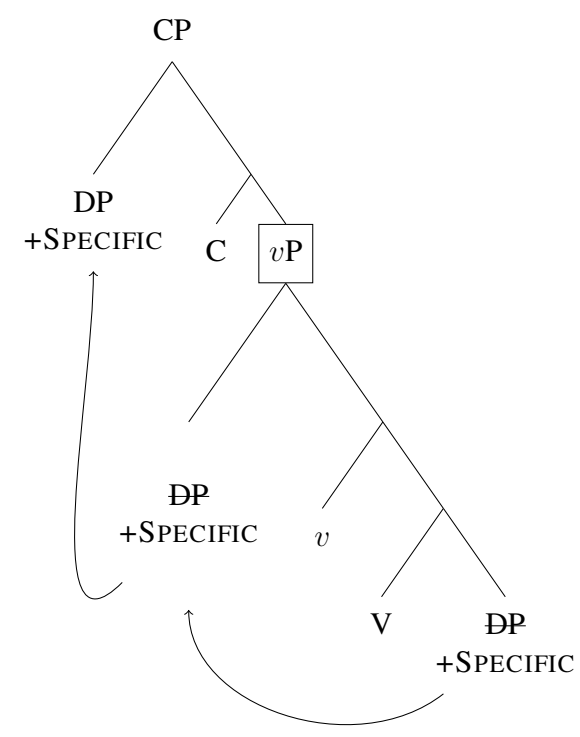

In Uyghur, however, $v$ is not a phase head. Rather, I hypothesize that a higher middle-field functional head $\mathrm{F}$ is. ${ }^{6}$ Hence, in Uyghur the phasal boundary is above $v \mathrm{P}{ }^{7}$ The crucial factor, is that since the phasal boundary is not $v \mathrm{P}$, moving DPs in Uyghur do not have to move to Spec $v \mathrm{P}$ as an intermediate landing site when moving to the left-periphery. The moving DPs move to Spec FP as an intermediate landing site, where there is no restriction (unlike Spec $v \mathrm{P}$ ) on whether the DP merged has a [+SPECIFIC] feature. ${ }^{8}$ Therefore, the scrambled objects in Uyghur can have either a specific or non-specific interpretation. Below is a sketch of the Uyghur-type derivation (23).

\footnotetext{
${ }^{6}$ On the proposed analysis the exact identity of which functional head is a phase head and delimits the phasal boundary in Uyghur is not relevant, the key point is that there must be a difference in phasal boundaries between the Turkish and Uyghur middle-field.

${ }^{7}$ Note that the present proposal assumes a contextual approach to phases where phasal domains are not fixed but can vary depending on the syntactic context (Bobaljik \& Wurmbrand 2005; den Dikken 2007; Gallego 2010; Bošković 2014). For example, Bošković's (2014) implementation of this approach, the highest projection in the domain of a lexical head-i.e. $\mathrm{N}, \mathrm{P}, \mathrm{A}$, and $\mathrm{V}$, is a phase. In this system, then the highest element in Turkish's $\mathrm{V}$ domain is $v$, but in Uyghur the highest element is a functional projection $\mathrm{F}$ above $v$. Hence, $v \mathrm{P}$ is not a phase in Uyghur, since $v$ is not the highest element in the $\mathrm{V}$ domain. The present proposal does not adopt any particular approach to contextual phases, rather that the proposed phasal variability between Turkish and Uyghur can be implemented given any number of existing theoretical frameworks.

${ }^{8}$ As to what triggers the initial movement step, one possibility is that it is a last resort operation to prevent the DP from being sent to the interfaces with an uninterpretable feature and to be accessible to a higher probe as in Bošković (2007). See Rodríguez-Mondoñedo (2007) for an application of this system to DOM. Furthermore, Şener (2010) proposes that in Turkish, scrambling is feature driven movement, if this is the case in Uyghur as well, then presumably the DP must move to the phase edge to prevent being spelled-out with an unvalued feature.
} 


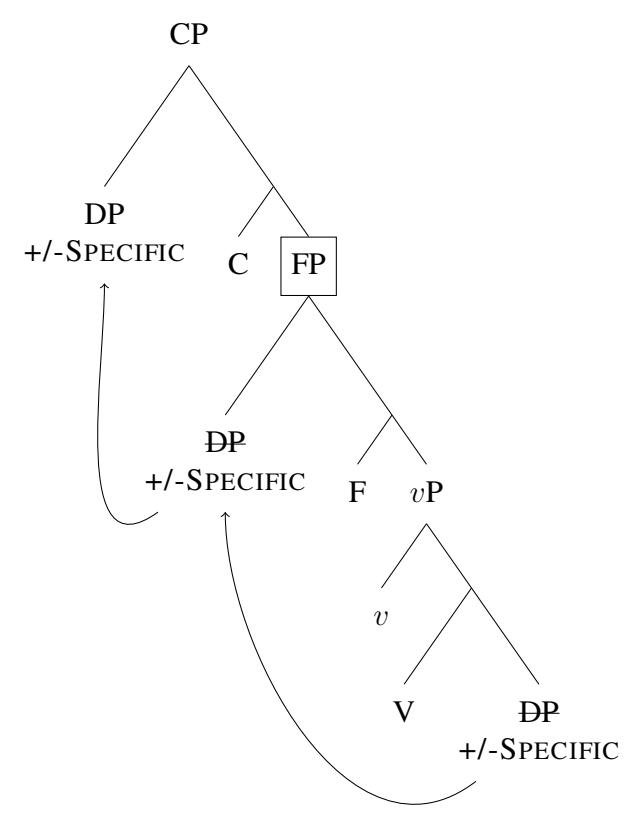

The contrast in available interpretations for Turkish and Uyghur's scrambled objects is not due to there being a difference in the way objects require licensing in each respective language. Rather, what drives the restriction on interpretation for objects is the position of phasal boundaries given the restriction on DPs being located in Spec $v \mathrm{P}$ being interpreted as [+SPECIFIC]. Because in Turkish the phase head is $v$ all moving DPs must bear a [+SPECIFIC] feature. But in Uyghur the phase head and $v$ are distinct. Hence, Uyghur makes available the possibility for moving objects to lack a specificity feature.

3.2. Phasal Variability. The hypothesized phasal variability observed in Turkish and Uyghur where in the former but not the latter $v$ is a phase head can be observed cross-linguistically for other phenomena. This variability is observed for whether moving DPs with $w h$-fronting have Spec $v \mathrm{P}$ as an intermediate landing site when moving to a left-peripheral position.

In Palauan (VOS; Austronesian), direct objects can control agreement on verbs (24-a) (Nuger 2010; Georgopoulos 1985). In configurations where an object DP has moved outside the $v \mathrm{P}$ as is the case with object relatives (24-b) or $w h$-fronting (24-c), the object agreement is preserved. Assuming that object agreement morphology is a reflex of the DP moving to Spec $v \mathrm{P}$, the Palauan data suggests that object DPs must have Spec $v \mathrm{P}$ as an intermediate landing site, when moving to higher position, which suggests that in Palauan $v$ is a phase head.
a. Te-'illebed-ii a bilis a rengalek
REL.3PL-PFV.hit-3SG.OBJ dog children
'The kids hit the dog' (Georgopoulos (1991), (15a))
b. $\quad$ a buk $_{i}$ [el 1-ulcher-ar $t_{i}$ a chad]
book COMP IRR.3-PF.buy-3SG.OBJ man
'The book that the man bought' (Chung \& Georgopoulos (1988), (10))
c. $\mathrm{Ng}$ te' $\mathrm{a}_{i}$ a l-ulekod-ir $t_{i}$ a rubak?
3SG= who 3SG.SBJ.IRR-kill.PRF-3SG.OBJ old.man
'who did the old man kill?' (Georgopoulos (1991), (48b)) 
The Palauan pattern stands in contrast with a language such as Kinande (SVO; Bantu). As illustrated in (25-a), direct object DPs control the agreement morpheme. But when a wh-object is fronted as in (25-b), the object agreement morpheme does not surface (cf. (25-c)). Again, assuming that object agreement morphology is a reflex of DP to Spec $v \mathrm{P}$ movement, the Kinande pattern suggests that when a DP is moving to a higher position-i.e. Spec CP, the DP does not have Spec $v \mathrm{P}$ as an intermediate landing site (Bošković (2016) in fact provides such an analysis for Kinande).
a. $\quad\left[{ }_{I P}\right.$ Yosefu $\left[I^{\prime}\right.$ a-ka-ja $\quad$ EBIkEn $_{j} \quad$ Byo $_{j} \quad$ Marya $\left.]\right]$
Joseph AGR-TENSE-give yams(cl.8) AGR(cl.8) Mary(cl.1)
'Joseph is giving the yams to Mary'
b. $\left[{ }_{C P} \mathrm{EBIhI}_{j}\left[{ }_{C^{\prime}} \mathrm{ByO}_{j} \quad\left[{ }_{I P}\right.\right.\right.$ Yosefu akaha $\mathbf{t}_{j}$ Marya $\left.\left.]\right]\right]$
What(cl.8) WhAgR(cl.8) Joseph gives $\mathrm{t}_{j}$ Mary
'What is Joseph giving to Mary?'
What(cl.8) WhAGR(cl.8) Joseph gives $t_{j}$ AGR(cl.8) Mary
(Schneider-Zioga (1995); (4),(15ab))
c. $*\left[{ }_{C P} \mathrm{EBIhI}_{j}\left[{ }_{C^{\prime}} \mathrm{ByO}_{j} \quad\left[{ }_{I P}\right.\right.\right.$ Yosefu akaha $_{j} \mathbf{B y O}_{j} \quad$ Marya $\left.]\right]$

In light of the Palauan and Kinande contrast, I suggest that what Palauan and Kinande show with object agreement, Turkish and Uyghur show with specificity. In other words, both contrasts are instantiations of the same type of cross-linguistic variation, namely whether $v$ is a phase head and thus whether moving DPs must have Spec $v \mathrm{P}$ as an intermediate landing site when moving to a higher position. In Turkish and Palauan $v$ is a phase head; in Uyghur and Kinande it is not.

\subsection{Movement to Phas al Edges. As illustrated in (23), I proposed that in Uyghur DPs} proceed directly to the phasal edge, Spec FP, when moving to a left-peripheral position, without passing through Spec $v \mathrm{P}$ as an intermediate landing site. For [-SPECIFIC] DPs, this derivation is blocked anyways given the specificity-requirement on movement to Spec $v \mathrm{P}$. Note, however, that nothing would go wrong in principle if such a derivation as in (26) was available to [+SPECIFIC] DPs.

$$
\text { [CP doktorni } \left.\left.\left.{ }_{i}\left[\mathrm{TP} \text { men [FP } t_{i} \text { [vP }_{i} t_{\mathrm{VP}} t_{i} \text { izdewatimen] }\right]\right]\right]\right]
$$

There are, however, independent reasons to think (26) is not a possible derivation in Uyghur and so both specific and non-specific DPs move directly from their base-generated position to Spec FP. As was shown, in Kinande there was no possibility of optional object agreement with a fronted $w h$-object (25-c). This suggests that, in Kinande, a moving DP never has Spec $v \mathrm{P}$ as an intermediate landing site. Assuming that Uyghur's scrambled objects and Kinande's fronted whobjects are derivational parallels, then scrambled objects in Uyghur should never move to Spec $v \mathrm{P}$ either.

It has in fact been suggested that successive cyclic movement can only proceed through phasal edges (Kang 2014; Bošković 2020). Furthermore, it has been suggested that movement through a feature-checking position is generally not possible (Bošković 2008). For example, in (27), there is evidence that suggests that the $w h$-subject moves to the phase edge Spec CP, and does not pass through the feature-checking position Spec TP (Bošković 2020; Messick 2020).

$$
\text { [CP } \mathrm{Who}_{i}\left[\mathrm { TP } \left[{ }_{\mathrm{vP}} t_{i}\right.\right. \text { left?]]] }
$$

First, $w h$-subject DPs do move to Spec CP. One argument for this effect comes from 'aggres- 
sively non-d-linked' wh-phrases (Ginzburg \& Sag 2000; Pesetsky \& Torrego 2001). As (28-a), (28-b)) show, only wh-phrases in Spec CP can take the hell-modifiers. Given that in (28-c), the $w h$-subject modified with the hell is as grammatical as in (28-a), where the wh-object DP is in Spec CP, this suggests that the wh-subject DPs as in (28-c) are in Spec CP as well.
a. What the hell did you buy?
b. *Who bought what the hell?
c. Who the hell bought a car?

Second, there is evidence that the moving $w h$-subject DP does not have Spec TP as an intermediate landing site when moving to Spec CP. In West Ulster English, a moving $w h$-subject DP can float a quantifier following a passive verb as in (29-a). However, a regular non-wh subject DPs cannot (29-b) (McCloskey 2000).
a. Who was arrested all in Duke Street?
b. *They were arrested all last night.

This suggests that moving subject $w h$-phrases do not have Spec TP as an intermediate landing site when moving to Spec CP since the quantifier float in question is not possible from Spec TP. If this quantifier float was possible from Spec TP, (29-a) should be ungrammatical on par with (29-b). In other words, if movement proceeded first to Spec TP, and then to Spec CP, the derivations for (29-a) and (29-b) would be identical at the point in which the quantifier is floated. If this were the case, then quantifier float should be impossible in both cases.

Therefore, for the CP/TP domain movement must proceed directly to the phasal edge, it cannot stop in Spec TP even in a language where that position otherwise requires being filled. Previous research has suggested a number of proposals as to why Spec TP to Spec CP movement is prohibited. One suggestion is that such movement violates anti-locality constraints-i.e. ban movement that is too short (Bošković 2016; Erlewine 2020). Another proposal based on labeling considerations is presented in Bošković (2021).

The present analysis is neutral on which underlying mechanism best explains the issues under consideration. The salient point, however, is that given that there is a general prohibition on movement to Spec CP through Spec TP, we would expect similar restrictions to apply in the lower phasal domain as well. Namely, that in Uyghur, movement to Spec FP through Spec $v \mathrm{P}$ should not be possible either-i.e (26) is excluded. Hence, I suggest that the the same mechanism which forces subject wh-phrases to move directly to the Spec CP phase edge is what forces DPs in Uyghur to move directly to Spec FP. ${ }^{9}$

\footnotetext{
${ }^{9}$ Note that in both domains - CP/TP and FP/vP, when a DP has moved to CP or FP there is also a question of what mechanism explains Case-valuation (given there is no movement to Spec TP; Spec $v \mathrm{P}$ ). In the CP/TP domain for (27), nominative Case can be assigned to who via AGREE, at the point when T c-commands the wh-phrase. Another possibility is the system in Bošković (2007), where Case-valuation occurs when the DP probes its Case-licensor after movement-i.e. wh-subject probes T from Spec CP. For independent evidence for such Case-licensing (where relevant DP is base-generated in Spec CP) see Villa-García (2015). Regardless of the specific implementation, the same can apply to Uyghur's object DPs for accusative Case-valuation. Either $v$ probes DP before movement, or DP probes $v$ from Spec FP after movement. Presumably, the same applies to Kinande as well (see Bošković (2008)). In any case, the key observation is the parallel: as in the CP/TP domain where otherwise obligatory movement to Spec $\mathrm{TP}$ does not take place under movement to the higher phase edge, the otherwise obligatory movement to Spec $v \mathrm{P}$ does not take place under movement to the higher phase edge in the $\mathrm{FP} / v \mathrm{P}$ domain.
} 
4. Conclusion. In a well-known pattern for DOM languages, e.g. Turkish, DOM objects retain their specific interpretation under further movement to sentence initial position. In this paper, I show that Uyghur departs from this "standard" pattern. Here further movement of marked objects to a sentence initial position does not preserve an obligatory specific interpretation. This means that VP-externality is not a sufficient condition for a DP to have an obligatory specific interpretation, as has previous been assumed for DOM languages.

I proposed that the correct generalization for height and specificity is whether the object DP has moved to Spec $v \mathrm{P}$ during the derivation. In other words, it is not height relative to the VP which correlates with a DP receiving an obligatory specific interpretation, rather it is whether the DP occupies a particular position in the structure.

I have also proposed an analysis that is based off these observations. The analysis not only captures that variability in interpretation observed between Turkish and Uyghur, but also subsumes this variability as being an instance of a more general type of cross-linguistic variation, e.g. agreement, the source of which is the location of phasal boundaries.

\section{References}

Adger, David \& Daniel Harbour. 2007. Syntax and syncretisms of the person case constraint. Syntax 10(1). 2-37.

Aissen, Judith. 2003. Differential object marking: Iconicity vs. economy. Natural Language \& Linguistic Theory 21(3). 435-483.

Baker, Mark C \& Nadya Vinokurova. 2010. Two modalities of case assignment: case in Sakha. Natural Language \& Linguistic Theory 28(3). 593-642.

Bhatt, Rajesh \& Elena Anagnostopoulou. 1996. Object shift and specificity: Evidence from kophrases in Hindi. In Lise M. Dobrin, Lise M. McNair \& Kora Singer (eds.), CLS 32, 11-22. Chicago: Chicago Linguistic Society.

Bobaljik, Jonathan David \& Susi Wurmbrand. 2005. The domain of agreement. Natural Language \& Linguistic Theory 23(4). 809-865.

Bošković, Željko. 2007. On the locality and motivation of Move and Agree: An even more minimal theory. Linguistic Inquiry 38(4). 589-644.

Bošković, Željko. 2008. On successive cyclic movement and the freezing effect of feature checking. In Jutta Hartmann, Veronika Hegedús \& Henk C van Riemsdijk (eds.), Sounds of silence: Empty elements in syntax and phonology, 195-233. Amsterdam: Elsevier.

Bošković, Željko. 2014. Now i'ma phase, now i'm not a phase: On the variability of phases with extraction and ellipsis. Linguistic inquiry 45(1). 27-89.

Bošković, Željko. 2016. On the timing of labeling: Deducing comp-trace effects, the subject condition, the adjunct condition, and tucking in from labeling. The Linguistic Review 33(1). 17-66.

Bošković, Željko. 2020. Generalized asymmetry. Unpublished manuscript.

Bošković, Željko. 2021. Merge, move, and contextuality of syntax: The role of labeling, successive-cyclicity, and epp effects. Unpublished manuscript.

Chomsky, Noam. 2001. Derivation by phase. In Michael Kenstowicz (ed.), Ken hale: A life in language, 1-52. Cambridge: MIT Press.

Chung, Sandra \& Carol Georgopoulos. 1988. Agreement with gaps in Chamorro and Palauan. In Michael Barlow \& Charles A. Ferguson (eds.), Agreement in natural langauge: Approaches, theories, descriptions, 251-267. Stanford: CSLI Publications. 
Comrie, Bernard. 1989. Language universals and linguistic typology: Syntax and morphology. Chicago: University of Chicago Press 2nd edn.

Croft, William. 2002. Typology and universals. Cambridge: Cambridge University Press 2nd edn.

Dayal, Veneeta. 2011. Hindi pseudo-incorporation. Natural Language \& Linguistic Theory 29(1). $123-167$.

Diesing, Molly. 1992. Indefinites. Cambridge: MIT Press.

den Dikken, Marcel. 2007. Phase extension: Contours of a theory of the role of head movement in phrasal extraction. Theoretical Linguistics 33(1). 1-41.

Enç, Mürvet. 1991. The semantics of specificity. Linguistic Inquiry 22(1). 1-25.

Erguvanl1, Eser Emine. 1984. The function of word order in Turkish grammar. Berkeley: University of California Press.

Erlewine, Michael Yoshitaka. 2020. Anti-locality and subject extraction. Glossa: a journal of general linguistics 5(1). 84.

Gallego, Ángel J. 2010. Phase theory. Amsterdam: John Benjamins Publishing.

Georgopoulos, Carol. 1985. Variables in Palauan syntax. Natural Language \& Linguistic Theory 3(1). 59-94.

Georgopoulos, Carol. 1991. Syntactic variables: Resumptive pronouns and A' binding in Palauan. Dordrecht: Springer.

Ginzburg, Jonathan \& Ivan Sag. 2000. Interrogative investigations. Stanford: CSLI Publications. Hahn, Reinhard F. 1991. Spoken Uyghur. Seattle: University of Washington Press.

Harley, Heidi. 2002. Possession and the double object construction. In Pierre Pica (ed.), Linguistic variation yearbook, 31-70. Amsterdam: John Benjamins Publishing Company.

Kamali, Beste. 2011. Topics at the PF interface of Turkish. Cambridge: Harvard University dissertation.

Kang, Jungmin. 2014. On the absence of TP and its consequences: Evidence from Korean. Storrs: University of Connecticut dissertation.

Kelepir, Meltem. 2001. Topics in Turkish syntax: clausal structure and scope. Cambridge: Massachusetts Institute of Technology dissertation.

Kornfilt, Jaklin. 2003. Scrambling, subscrambling, and case in Turkish. In Simin Karimi (ed.), Word order and scrambling, 125-155. Oxford: Blackwell.

López, Luis. 2012. Indefinite objects: Scrambling, choice functions, and differential marking. Cambridge: MIT Press.

Marantz, Alec. 1991. Case and licensing. In Germán F. Westphal, Benjamin Ao \& Hee-Rahk Chae (eds.), ESCOL 8, 234-253. Ithaca: CLC Publications.

Massam, Diane. 2001. Pseudo noun incorporation in Niuean. Natural Language \& Linguistic Theory 19(1). 153-197.

McCloskey, James. 2000. Quantifier float and wh-movement in an Irish English. Linguistic Inquiry 31(1). 57-84.

Messick, Troy. 2020. The derivation of highest subject questions and the nature of the EPP. Glossa: a journal of general linguistics 5(1). 13.

Nuger, Justin. 2010. Architecture of the Palauan verbal complex. Santa Cruz: University of California- Santa Cruz dissertation.

Öztürk, Balkız. 2005. Case, referentiality, and phrase structure. Amsterdam: John Benjamins Publishing Company. 
Pesetsky, David \& Esther Torrego. 2001. T-to-C movement: Causes and consequences. In Michael Kenstowicz (ed.), Ken hale: A life in language, 355-426. Cambridge: MIT Press.

Rodríguez-Mondoñedo, Miguel. 2007. The syntax of objects: Agree and differential object marking. Storrs: University of Connecticut dissertation.

Sağ, Yağmur. 2019. The semantics of number marking: Reference to kinds, counting, and optional classifiers. New Brunswick: Rutgers University dissertation.

Schneider-Zioga, Patricia. 1995. Specifier/head agreement in Kinande. Cahiers linguistiques d'Ottawa 23. 67-93.

Şener, Serkan. 2010. (Non-) peripheral matters in Turkish syntax. Storrs: University of Connecticut dissertation.

Sinnemäki, Kaius. 2014. A typological perspective on differential object marking. Linguistics 52(2). 281-313.

Tömür, Hämit. 2003. Modern Uyghur grammar: morphology. Istanbul: Y1ld1z.

Torrego, Esther. 1998. The dependencies of objects. Cambridge: MIT Press.

Üntak-Tarhan, Fatma Asl1. 2006. Topics in syntax-phonology interface in turkish: Sentential stress and phases. Istanbul: Boğaziçi University MA thesis.

Villa-García, Julio. 2015. The syntax of multiple-que sentences in Spanish: Along the left periphery. Amsterdam: John Benjamins Publishing Company.

Wiltschko, Martina \& Elizabeth Ritter. 2015. Animating the narrow syntax. The Linguistic Review 32(4). 869-908. 